\title{
Genotoxic Potential of Shrimp Pastes (Belacan) Extracts Using Umu Test
}

\author{
Ahmad Rohi Ghazali ${ }^{*}$, Yvonne Sipain ${ }^{2}$, Nor Fadilah Rajab ${ }^{1}$, Siew Ee Ling ${ }^{1}$, Norain Ramli ${ }^{1}$, \\ Rozaini Abdullah $^{1,2}$, Zaliha Harun ${ }^{1}$, Firdaus Kamarulzaman ${ }^{1}$ \\ ${ }^{1}$ Biomedical Science Program, Faculty of Health Sciences, School of Diagnostic and Applied Health Sciences, Universiti Kebang- \\ saan Malaysia, Kuala Lumpur, Malaysia; ${ }^{2}$ Environmental Health Program, Faculty of Health Sciences, School of Diagnostic and \\ Applied Health Sciences, Universiti Kebangsaan Malaysia, Kuala Lumpur, Malaysia. \\ Email: *rohi@medic.ukm.my
}

Received January $27^{\text {th }}, 2012$; revised March $2^{\text {nd }}, 2012$; accepted March $10^{\text {th }}, 2012$

\begin{abstract}
This study was conducted to observe the genotoxic effects of aqueous, methanol, hexane and dichloromethane extracts of "belacan" (shrimp paste) taken from three local districts in Melaka, Malaysia (Kelemak, Batang Tiga \& Pantai Puteri). The umu test which was used as the screening test was conducted with and without the presence of metabolic activation system. Without the presence of metabolic activation system, aqueous extracts from Kelemak showed mutagenicity activity at $5 \mathrm{mg} / \mathrm{ml}$ with IR (Induction Rate) $=1.52 \pm 0.57$ and the methanol extracts showed mutagenic activities at $0.625 \mathrm{mg} / \mathrm{ml}$ and $5 \mathrm{mg} / \mathrm{ml}$, which the IR was the highest at $5 \mathrm{mg} / \mathrm{ml}(2.08 \pm 0.09)$. On the other hand, sam- ples from Batang Tiga, Melaka showed mutagenic effects at all five concentrations for the dichloromethane extract, with IR = $2.09 \pm 0.64$ as the highest value at $1.25 \mathrm{mg} / \mathrm{ml}$. Methanol extracts also showed positive results at $1.25 \mathrm{mg} / \mathrm{ml}$ and 2.5 $\mathrm{mg} / \mathrm{ml}$ with IR $=1.70 \pm 0.33$ and $\mathrm{IR}=2.12 \pm 0.51$ respectively, and aqueous extract at $0.625 \mathrm{mg} / \mathrm{ml}$ with $\mathrm{IR}=1.54 \pm$ 0.48 and $5 \mathrm{mg} / \mathrm{ml}$ with IR $=1.74 \pm 0.50$. There was a significant difference of the mean values of IR between the four different types of "belacan" extracts from Batang Tiga $(\mathrm{p}<0.05)$. All four "belacan" extracts from Pantai Puteri, Melaka did not show any mutagenic effect. With the presence of metabolic activation system, there was no mutagenic effect observed in all four extracts from the three districts. Further study to analyze the contents in the food samples should be done in the future to determine the possible contents in the food samples that might be responsible for the mutagenic activities.
\end{abstract}

Keywords: Shrimp Pastes; Mutagenicity; Umu Test; Melaka; Genotoxicity

\section{Introduction}

Various factors such as the environment, diet, lifestyle, health status and genetics can influence human health. Diet along with alcohol consumption and smoking habit are the most significant factors of different kinds of diseases [1]. In addition, various evidences from ecological and experimental experiments showed that diet has a role in the etiology of cancers.

"Belacan" (shrimp paste) is one of the most consumed local raw food products daily in Malaysia [2]. It is made from wet shrimps fermented with $10 \%-15 \% \mathrm{w} / \mathrm{w}$ of salt. According to Arshad et al. [3] "belacan" is enlisted as one of the seven foods that associated with cancer which are anchovies, dried fish, salted fish, shrimp paste, pickled fruits, salted egg and pickled vegetable. Salted fish has been proven to be carcinogenic to human [4]. Salted fish is found to contain high content of nitrosamine as

\footnotetext{
"Corresponding author.
}

well as a few other chemicals [5].

Toxicological evaluations on several raw food products had been done by Ghazali et al. [6] and "belacan" at $62.5 \mu \mathrm{g} / \mathrm{ml}$ caused the highest DNA damage on Chang liver cells, followed by salted fish, anchovies and dried shrimps. Studies on animals had shown that $10 \%$ of salt in diet causes the induction of mucosal damage such as cell degeneration, and further destroy the mucosal membrane lining the rat gaster [7]. Further studies of chemical analysis and animal experiments have to be conducted in order to examine into details about the carcinogenic potential of food products preserved by salting treatment. Preservation process using salt and drying can also lead to the formation of N-nitroso compounds. Nitrite in salts will form a reaction with amides and amines in meats or proteins which produces $\mathrm{N}$-nitroso compounds [8]. The objective of this study was to evaluate genotoxicity potential of shrimp paste from Malaysia using umu test. 


\section{Methodology}

\subsection{Sampling}

Food samples were obtained by simple random sampling method in Malacca, which is one of the main producers of "belacan" in Malaysia. Samples are selected from three local districts which are Kelemak, Pantai Puteri and Batang Tiga. Extraction using dichloromethane, methanol, hexane and aqueous were done for sample preparation. Dichloromethane and hexane are non-polar solvent, methonal is a polar protic solvent and water is the most polar solvent [9].

\subsection{Umu Test}

The method for analysis was umu test whereby the Salmonella typhimurium TA1535/pSK1002 strain was obtained from Professor Dr. I Aoyama from Okamaya University, Japan. Salmonella typhimurium TA1535/ pSK1002 was used in umu test. Salmonella typhimurium TA1535/pSK1002 was derived from its precursor strain which was Salmonella typhimurium TA98, a mutant bacteria. This strain carries plasmid pSK1002 harboring a fusion gene umuC'-lacZ. Plasmid pSK1002 also coded the genes for ampicilin resistance. The genetic markers of this strain were hisG, uvrB, rfa, umu-ClacZ and amp. The umu test had been standardized by the German Institute for Standardization (DIN 38415 T3) and also by
ISO (ISO/DIS 13829, 2000) to detect genotoxins in various compounds including environmental and food samples.

The samples were tested with and without the S9 metabolic system [10]. S9 mix is a liver enzymes fraction pooled from male Sprague-Dawly (Sigma-Aldrich) and used for activation of promutagen substances to mutagen. Protocols for umu test consisted of genetic analysis, growth curve, and preparation of bacteria stock and umu test. For the umu test, IR (Induction Rate) $=1.5$ is reported as a positive result [11-13], 4-nitroquinoline-1oxide (4-NQO) (for without S9 metabolic system) and 2-aminoanthracene (2-AA) (with presence of S9 metabolic system) were also used as the positive controls.

\section{Results and Discussion}

Tables 1-3 showed result of umu test without the metabolic activation. Results showed that methanol and aqueous extracts of "belacan" samples from Kelemak were mutagenic (Table 1). Methanol extract was mutagenic at $5 \mathrm{mg} / \mathrm{ml}(\mathrm{IR}=2.08 \pm 0.09)$ and at $0.625 \mathrm{mg} / \mathrm{ml}$ $(\mathrm{IR}=1.72 \pm 0.84)$ whereas the aqueous extracts at 5 $\mathrm{mg} / \mathrm{ml}(\mathrm{IR}=1.52 \pm 0.57)$. Table 2 showed Pantai Puteri samples did not cause any mutagenic effects. While sampels from Batang Tiga showed mutagenic effects at all concentrations with dichloromethane extraction with the highest IR $=2.09 \pm 0.64$ at $1.25 \mathrm{mg} / \mathrm{ml}$ (Table 3). Metha-

Table 1. IR of "belacan” extracts from Kelemak, Melaka without metabolic activation.

\begin{tabular}{|c|c|c|c|c|}
\hline Concentration (mg/ml) & Dichloromethane & Hexane & Methanol & Aqueous \\
\hline 0.3125 & $0.41 \pm 0.05$ & $0.77 \pm 0.38$ & $1.27 \pm 0.58$ & $1.01 \pm 0.26$ \\
\hline 0.625 & $0.74 \pm 0.39$ & $0.90 \pm 0.33$ & $1.72 \pm 0.84^{*}$ & $1.08 \pm 0.43$ \\
\hline 1.25 & $0.49 \pm 0.22$ & $0.97 \pm 0.32$ & $1.3 \pm 0.31$ & $1.05 \pm 0.44$ \\
\hline 2.5 & $0.45 \pm 0.19$ & $1.13 \pm 0.24$ & $1.25 \pm 0.19$ & $1.35 \pm 0.61$ \\
\hline 5 & $0.76 \pm 0.01$ & NA & $2.08 \pm 0.49^{*}$ & $1.52 \pm 0.57^{*}$ \\
\hline 4-NQO & $2.02 \pm 0.38$ & $1.82 \pm 0.28$ & $1.82 \pm 0.09$ & $1.90 \pm 0.26$ \\
\hline
\end{tabular}

* Significantly difference as compared to control.

Table 2. IR of "belacan” extracts from Pantai Puteri, Melaka without metabolic activation.

\begin{tabular}{cccc}
\hline Concentration $(\mathrm{mg} / \mathrm{ml})$ & Dichloromethane & Hexane & Methanol \\
\hline 0.3125 & $1.20 \pm 0.62$ & $0.72 \pm 0.32$ & $1.31 \pm 0.08$ \\
0.625 & $1.23 \pm 0.53$ & $0.99 \pm 0.17$ & $0.99 \pm 0.33$ \\
1.25 & $1.16 \pm 0.34$ & $1.19 \pm 0.3$ & $1.15 \pm 0.55$ \\
2.5 & $1.41 \pm 0.24$ & $0.96 \pm 0.12$ & $1.26 \pm 0.36$ \\
5 & $1.31 \pm 0.38$ & $0.87 \pm 0.36$ & $1.40 \pm 0.38$ \\
$4-\mathrm{NQO}$ & $2.02 \pm 0.38$ & $1.82 \pm 0.28$ & $1.38 \pm 0.41$ \\
\hline
\end{tabular}


nol extracts of Batang Tiga showed mutagenic effects at $1.25 \mathrm{mg} / \mathrm{ml}(\mathrm{IR}=1.7 \pm 0.33)$ and $2.5 \mathrm{mg} / \mathrm{ml}(\mathrm{IR}=2.12 \pm$ 0.52). Meanwhile, aqueous extracts of Batang Tiga were mutagenic at $0.625 \mathrm{mg} / \mathrm{ml}(\mathrm{IR}=1.54 \pm 0.48)$ and 5 $\mathrm{mg} / \mathrm{ml}(\mathrm{IR}=1.74 \pm 0.5)$. All extracts showed no mutagenic effect when tested using umu test with the presence of metabolic activation S9 (Tables 4-6).

There are a few factors that might cause the observed positive results. According to previous studies by Sharif et al. [14], salt content analysis on "belacan" samples obtained from Malacca was 20\%, whereby Sumino et al. [15] found that "belacan" processed in Malaysia contain approximately $24.1 \%$ salt. According to Malaysian Food Act 1983, the standard of salt content for "belacan" should be around $15 \%$. High concentration of salt can lead to chromosome breakage [16], cell death and also can induce DNA damage [6]. According to Cohen \& Roe [16], sometimes, the usage of salts contaminated with nitrite and nitrates can also lead to nitrosamines contamination in foods. It is also suggested that the presences of $\mathrm{N}$-nitroso compounds is one of the factors that can also lead to risk of cancer.

The extracts of "belacan" only showed mutagenic effects without metabolic activation. S9 metabolic active-

Table 3. IR of “belacan” extracts from Batang Tiga, Melaka without metabolic activation.

\begin{tabular}{ccccc}
\hline Concentration $(\mathrm{mg} / \mathrm{ml})$ & Dichloromethane & Hexane & Methanol & Aqueous \\
\hline 0.3125 & $1.77 \pm 0.68^{*}$ & $1.13 \pm 0.28$ & $1.11 \pm 0.27$ & $1.33 \pm 0.27$ \\
0.625 & $1.73 \pm 0.72^{*}$ & $0.90 \pm 0.18$ & $1.04 \pm 0.13$ & $1.54 \pm 0.48^{*}$ \\
1.25 & $2.09 \pm 0.64^{*}$ & $1.07 \pm 0.12$ & $1.70 \pm 0.33^{*}$ & $1.39 \pm 0.55$ \\
2.5 & $2.07 \pm 0.4^{*}$ & $1.01 \pm 0.42$ & $2.12 \pm 0.52^{*}$ & $1.40 \pm 0.57$ \\
5 & $2.05 \pm 0.15^{*}$ & $1.10 \pm 0.17$ & $1.38 \pm 0.57$ & $1.74 \pm 0.5^{*}$ \\
$4-\mathrm{NQO}$ & $2.02 \pm 0.38$ & $1.82 \pm 0.28$ & $1.82 \pm 0.09$ & $1.90 \pm 0.26$ \\
\hline
\end{tabular}

*Significantly difference as compared to control.

Table 4. IR of "belacan” extracts from Kelemak, Melaka with metabolic activation.

\begin{tabular}{ccccc}
\hline Concentration $(\mathrm{mg} / \mathrm{ml})$ & Dichloromethane & Hexane & Methanol & Aqueous \\
\hline 0.3125 & $0.77 \pm 0.13$ & $0.81 \pm 0.13$ & $1.01 \pm 0.05$ & $0.89 \pm 0.21$ \\
1.25 & $0.815 \pm 0.01$ & $0.765 \pm 0.06$ & $1.05 \pm 0.08$ & $0.85 \pm 0.02$ \\
5 & $1.06 \pm 0.33$ & $0.95 \pm 0.25$ & $0.82 \pm 0.23$ & $0.63 \pm 0.13$ \\
2 -AA & $1.61 \pm 0.01$ & $1.61 \pm 0.01$ & $1.8 \pm 0.25$ & $2.03 \pm 0.01$ \\
\hline
\end{tabular}

Table 5. IR of "belacan” extracts from Pantai Puteri, Melaka with metabolic activation.

\begin{tabular}{ccccc}
\hline Concentration $(\mathrm{mg} / \mathrm{ml})$ & Dichloromethane & Hexane & Methanol & Aqueous \\
\hline 0.3125 & $0.97 \pm 0.1$ & $0.81 \pm 0.01$ & $0.87 \pm 0.07$ & $0.90 \pm 0.25$ \\
1.25 & $0.98 \pm 0.16$ & $0.76 \pm 0.11$ & $0.91 \pm 0.12$ & $0.98 \pm 0.06$ \\
5 & $0.67 \pm 0.21$ & $0.83 \pm 0.23$ & $0.85 \pm 0.03$ & $0.7 \pm 0.13$ \\
2 2-AA & $1.61 \pm 0.01$ & $1.61 \pm 0.01$ & $1.8 \pm 0.25$ & $2.03 \pm 0.01$ \\
\hline
\end{tabular}

Table 6. IR of “belacan” extracts from Batang Tiga, Melaka with metabolic activation.

\begin{tabular}{cccc}
\hline Concentration $(\mathrm{mg} / \mathrm{ml})$ & Dichloromethane & Hexane & Methanol \\
\hline 0.3125 & $1.11 \pm 0.31$ & $0.85 \pm 0.13$ & $0.72 \pm 0.04$ \\
1.25 & $1.09 \pm 0.23$ & $0.73 \pm 0.15$ & $0.83 \pm 0.17$ \\
5 & $1.13 \pm 0.25$ & $0.86 \pm 0.16$ & $0.82 \pm 0.11$ \\
2-AA & $1.61 \pm 0.01$ & $1.61 \pm 0.01$ & $1.8 \pm 0.25$ \\
\hline
\end{tabular}


tion system acts as an enzyme for the metabolism of xenobiotic compounds whereby toxic compounds will undergo biotransformation into less toxic compounds [17]. Therefore, mutagens that are present in the samples could have been transformed into less toxic compounds and do not show any mutagenic activity.

\section{Conclusion}

The study showed that the "belacan" samples were found to induce genetic damage to Salmonella thyphimurium without the presence of metabolic activation. However, samples tested with umu test with the presence of metabolic activation did not show any positive result.

\section{Acknowledgements}

We are truly grateful to all the research assistants of Biocompatibility Laboratory, Faculty of Health Sciences, Universiti Kebangsaan Malaysia for their contribution in terms of knowledge and assistance and also to National Cancer Agency of Malaysia (MAKNA) for granting this research.

\section{REFERENCES}

[1] B. T. Smith and G. C. Walker, "Mutagenesis and More: umuDC and the Escherichia Coli SOS Response," Genetics, Vol. 148, No. 4, 1998, p. 1599.

[2] B. S. Gendeh, S. Murad, A. M. Razi, N. Abdullah, A. S. Mohamed and K. A. Kadir, "Skin Prick Test Reactivity to Foods in Adult Malaysians with Rhinitis,” Otolaryngology-Head and Neck Surgery, Vol. 122, No. 5, 2000, pp. 758-762. doi:10.1016/S0194-5998(00)70211-7

[3] F. Arshad, L.P.K., L. H. Yee, S. Nooriah, S. Suzana, A. T. Ruzita, M. S.Lingam and E. P. Tan, "A Retrospective Case-Control Study: The Association Between Dietary Intake and Cancer,” Department of Nutrition and Dietetics, UKM, National Cancer Council, 2005.

[4] IARC, "Some Naturally Occurring Substances: Food Items and Constituents, Heterocyclic Aromatic Amines and Mycotoxins. IARC Monographs on the Evaluation of Carcinogenic Risks to Humans,” IARC, Lyon, 1993.

[5] T. Kawabata, J. Uibu, H. Ohshima, M. Matsui, M. Hamano and H. Tokiwa, "Occurrence, Formation and Precursors of N-Nitroso Compounds in the Japanese Diet," IARC Scientific Publications, Vol. 31, 1980, p. 481.

[6] A. R. Ghazali, N. F. Rajab, R. Sharif, T. A. Yaakob and F. Arshad, "The Genotoxicological Evaluation of Several Local Raw Foods Extracts on Chang Liver Cells by Single Cell Electrophoresis Assay,” Environmental Mutagen Research, Vol. 27, No. 3, 2005, pp. 165-170.

doi:10.3123/jems.27.165
[7] M. Takahashi and R. Hasegawa, "Enhancing Effects of Dietary Salt on Both Initiation and Promotion Stages of Rat Gastric Carcinogenesis,” In: Y. Hayashi, et al., Eds., Diet, Nutrition and Cancer, Japan Science Society Press, Utrecht, 1986, pp. 169-182.

[8] R. K. Phukan, K. Narain, E. Zomawia, N. C. Hazarika and J. Mahanta, "Dietary Habits and Stomach Cancer in Mizoram, India,” Journal of Gastroenterology, Vol. 41, No. 5, 2006, pp. 418-424.

doi:10.1007/s00535-006-1761-X

[9] M. Haidekker, T. Brady, D. Lichlyter and E. Theodorakis, "Effects of Solvent Polarity and Solvent Viscosity on the Fluorescent Properties of Molecular Rotors and Related Probes,” Bioorganic Chemistry, Vol. 33, No. 6, 2005, pp. 415-425. doi:10.1016/j.bioorg.2005.07.005

[10] K. Mortelmans and E. Zeiger, "The Ames Salmonella/ Microsome Mutagenicity Assay," Mutation Research/ Fundamental and Molecular Mechanisms of Mutagenesis, Vol. 455, No. 1-2, 2000, pp. 29-60.

[11] B. Hamer, N. Bihari, G. Reifferscheid, R. K. Zahn, W. Müllerc and R. Batel, "Evaluation of the SOS/Umu-Test Post-Treatment Assay for the Detection of Genotoxic Activities of Pure Compounds and Complex Environmental Mixtures,” Mutation Research/Genetic Toxicology and Environmental Mutagenesis, Vol. 466, No. 2, 2000, pp. 161-171. doi:10.1016/S1383-5718(00)00016-4

[12] K. Ozturk and M. Durusoy, "The Detection and Comparison of the Genotoxic Effects of Some Nitro Aromatic Compounds by the Umu and SOS Chromotest Systems," Toxicology Letters, Vol. 108, No. 1, 1999, pp. 63-68. doi:10.1016/S0378-4274(99)00117-4

[13] L. Verschaeve and J. Van Staden, "Mutagenic and Antimutagenic Properties of Extracts from South African Traditional Medicinal Plants," Journal of Ethnopharmacology, Vol. 119, No. 3, 2008, pp. 575-587. doi:10.1016/j.jep.2008.06.007

[14] R. Sharif, A. Ghazali, N. Rajab, H. Haron and F. Osman, "Toxicological Evaluation of Some Malaysian Locally Processed Raw Food Products," Food and Chemical Toxicology, Vol. 46, No. 1, 2008, pp. 368-374. doi:10.1016/j.fct.2007.08.010

[15] T. Sumino, S. Kageyama, E. Endo, R. Chihara and K. Yamada, "Components and Bacterial Content of Belacan Produced in Malaysia," Journal of Cookery Science of Japan, Vol. 36, No. 2, 2003, pp. 164-169.

[16] A. Cohen and F. Roe, "Evaluation of the Aetiological Role of Dietary Salt Exposure in Gastric and Other Cancers in Humans," Food and Chemical Toxicology, Vol. 35, No. 2, 1997, pp. 271-293. doi:10.1016/S0278-6915(96)00114-7

[17] E. Hodgson and P. E. Levi, "A Textbook of Modern Toxicology,” Wiley Online Library, 2004. doi:10.1002/0471646776 